\title{
Assessment of Broiler Production; Processing and Marketing Practices in Ethiopia: Identifying the Root Causes for Poultry Products Importation and Way Forward
}

\section{ISSN: 2640-9208}

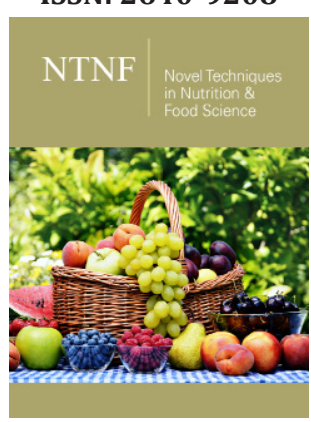

${ }^{* 1}$ Corresponding author: Tekeba Eshetie, Ethiopia Meat and Dairy Industry Development Institute, Ethiopia

Submission: 酶October 16, 2019

Published: 眥 November 04, 2019

Volume 4 - Issue 4

How to cite this article: Tadesse $\mathrm{T}$, Elfinesh B, Birhanu M, Seyum H, Tekeba E. Assessment of Broiler Production; Processing and Marketing Practices in Ethiopia: Identifying the Root Causes for Poultry Products Importation and Way Forward. Nov Tech Nutri Food Sci. 4(4). NTNF.000591.2019.

DOI: 10.31031/NTNF.2019.04.000591

Copyright@ Tekeba Eshetie, Sinézio I S. This article is distributed under the terms of the Creative Commons Attribution 4.0 International License, which permits unrestricted use and redistribution provided that the original author and source are credited.
Tadesse Teshome, Elfinesh Bekele, Birhanu Million, Seyum Hagos and Tekeba Eshetie*

Ethiopia Meat and Dairy Industry Development Institute, Ethiopia

\begin{abstract}
As opposed to the high national demand for broiler meat in Ethiopia, the production and processing companies are not benefited from the market. A huge amount of broiler meat has been imported to Ethiopia by International star hotels, supermarkets and Ethiopian airlines from different parts of the world. Therefore, this research work is initiated to assess the status of broiler production and processing practices in Ethiopia so as to identify major causes of poultry products importations and propose the way forward. The research is basically a field study supplemented with secondary data from the national and international data sources. The primary data was collected from selected broiler producers, processors, supermarkets and international star hotels and Ethiopian airlines. This research was conducted in purposively selected sites where you find broilers production, processing establishments and the market. For the interview purpose, 21 broiler farms and 4 broiler meat processors were used. The collected data was analyzed using descriptive statistics and SPSS. The result of this study generally indicated that the broiler production systems observed by the study team is classified into two broad categories, commercial broiler production system and small-scale broiler production system. Facilities used in both production systems are different based on their investment capacity, level of their knowledge, input access and scope of their market outlets. In both production systems and processing units, there is no standard for their products, traceability for their products is very challenging and the type of transport system they are using for their products is not up to the standard.
\end{abstract}

The informal marketing channel is dominant, the application of international food safety measures like ISO, HACCP and GMP are literally absent, shortage of skilled manpower in the sector is a very serious problem and the market information system and access to credit and incentive is very shallow. The other challenge is the involvement of the middlemen in the marketing process who take the major share of the margin. Therefore, because of these interlinked challenges and others, the producers and processors are not benefited from their business as a result there is continuous broiler meat imported from other parts of the world. Hence, there are efforts to continue capacity building in-terms of man power, facilities, access to credit, strategic incentives, market information system, issuance of rules and regulations for binding challenges in marketing, products traceability system, cold chain facilities, policy direction in products importation, food safety measures and investment promotion in production and processing are very important. Strong and sustainable linkage among major stakeholders is very crucial as well. Further research is needed to see the origin of the products, trends and the actors involved.

Keywords: Importation; Marketing; Processing; Production

\section{Introduction}

Poultry production and product consumption are gradually growing in the world. Poultry accounts for about $33 \%$ of the global meat consumption and is expected to grow at 2 to $3 \%$ per year in the world. Several publications indicate that large size poultry farms were more efficient, but these farms are few in the developing countries. As one of developing country, Ethiopian poultry sector is not yet to satisfy the growing needs of customers. The data shows that contribution of the subsector to the GDP is estimated 4.172 million ETB per year. According to CSA [1], in Ethiopia there exists around 60.04 million chicken populations of which $88 \%$ indigenous, $2.79 \%$ hybrid and $1.35 \%$ exotic breeds. The estimated annual production of poultry meat in Ethiopia is 61,840 tons, which accounts for $1.3 \%$ share of the production in Africa and $11.7 \%$ of East Africa [2]. As a country to address the protein demand and improve 
the livelihood of the people, development of poultry production and processing sectors are some of the focus areas by the government. Towards to this end, the livestock master plan document was produced to serve as national guiding document.

Against the government poultry development strategy, now a day, a huge amount of broiler meat is imported from different countries to Ethiopia by Ethiopian airlines, by five-star hotels like Sheraton Addis, Hilton, Radisson Blue and others. Ethiopian airline alone has been importing 2,000kg of broiler meat every day from Brazil and South Africa and other sources. As a result of this, the local chicken meat processors are not benefiting and complaining on the lack of reliable market system in the country and demanding some market protections from the government. Similarly, the country is scarifying its meager foreign currency resources by importing these products. Therefore, this study is initiated to evaluate the current broiler production and processing and marketing activities in Ethiopia and to identify the major reasons why we import broiler meat from outside world and to propose possible solutions with the following specific objectives.

\section{Research Objectives}

a) To assess the current broiler production activities, facilities used, production premises

b) To assess the broiler processing techniques, their facilities, logistics and local marketing routs, market actors and their day to day challenges

c) To study the major causes of poultry products importation and product type and market actors

\section{Classification of respondents and sample size}

Table 1: Classification of respondents and sample size.

\section{Methodology of the Study}

\section{Study sites}

This study has been conducted at selected sites of Oromia (Adama, Bishoftu, Awash, Modjo, Addis Ababa and Hawasa (SNNP) where we can find more broiler production and processing establishments. The target groups for the study include; broiler producers of all kinds; broiler meat processors; supermarkets; resource people from major and relevant sectors; retail traders' consumers and researchers. The research is a field study and utilizes different data sources including primary and secondary data. Regarding the primary data sources, pretested questionnaires were used for the interview and conducted among sample respondents selected from relevant organizations. Also check list were used for interviewing Hotels, Ethiopian Airlines people and supermarkets. Continuous observation of broiler production and processing units and face to face discussions with focus groups was made and key stakeholders were also selected for more data collection. Secondary source of data came from books, and journals, research outputs, CSA data etc. The data was analyzed using descriptive and excel sheet as required.

\section{Sample size determination and procedures}

Since the population was not large enough and not all the broiler producers in the country are formal, the researcher decided to come up with a sampling frame which involves people whose activities affect the poultry business in one way or the other. There is one main type of sampling techniques chosen for this study, judgmental sampling technique; also called purposive sampling, which was used to select respondents.

\begin{tabular}{|c|c|c|}
\hline No. & Respondent Category & Number \\
\hline 1 & Broiler producers & 21 \\
\hline 2 & Broiler processors & 4 \\
\hline 3 & Chicken meat collectors & 3 \\
\hline 4 & Supermarkets & 6 \\
\hline 5 & International hotels & 13 \\
\hline 6 & Ethiopian Airline catering department & 1 \\
\hline 7 & Total & 48 \\
\hline
\end{tabular}

Based on the use of judgmental sampling techniques respondents were classified as shown in Table1.

\section{Data collection}

In designing the questionnaire, both open and closed ended questions were used depending on the situation. This was to ensure that information obtained was accurate and could be reliable. Free interviews and focus group discussion were used to request information relevant to the study from some respondents.

\section{Data analysis}

In this study, the researcher relied on Microsoft Excel and descriptive statistics as required in analyzing the data. Frequency dis- tribution, percentages, bar charts and descriptive analysis evaluating the challenges and prospects of broiler production, processing and marketing in the country used to examine the research questions [2].

\section{Result and Discussion}

The study considers demographic characteristics such as gender, age, and educational level which are relevant and important to the study. This is so because these characteristics show the various classes of respondents and how the classes influence the perceptional views, choices, preferences, etc associated with the topic [3]. In general, the demographic profile indicated that $90.5 \%$ of the re- 
spondents are males and the rest of the balance is female respondents as indicated in Figure 1. According to respondents, the broiler production and processing business is considered to be laborious and quite a risky venture, which also needs capital. This explains why the industry attracts more males than females. As it is observed the age classification of the respondents within the survey, the highest percentage fall within the age of 30 . This indicated that the involvement of the experienced people become evident for the industry to be more sustainable and competitive in the market. As indicated in Figure 2, more educated people (85.71\%) is involved in the sector which is also a solid foundation for transfer of modern technology. The major share of the respondents with diplomas in related fields (agriculture, marketing, and management) is also important to easily understand the poultry business and can properly manage their farms. The remaining respondents also understand poultry farming and selling chickens but do not know about the modern system of production in the poultry industry. It is also observed that a number of farms have managers but most of the farms are managed by the owners themselves. These educated personnel in the field are directly involved in both the technical as well as managerial activities which also minimizes the overhead costs [4].

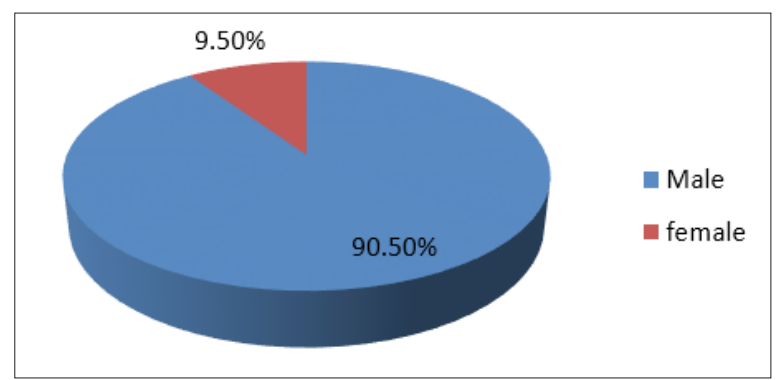

Figure 1: Respondent's classification.

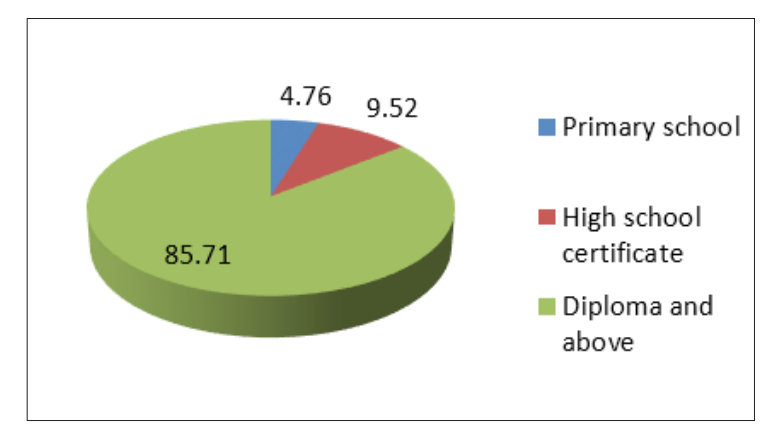

Figure 2: Educational Background of Respondents.

\section{Broiler production systems}

Broiler production systems observed by the study team can be classified in two different categories.

1. Commercial broiler production system: which is an intensive production system involving an average of 10,000 broilers kept under indoor conditions as one batch with a medium bio-security level (Alema and Elfora farms). Comparatively those farms are well experienced and required intensive inputs such as feed, housing, health, and modern management systems. In this case the number of employees is more, and the invested capital is relatively higher as compared to small scale broiler farms. Usually the source of their replacement stock is either imported or from their broiler parent stock.

2. Small scale broiler production system is also engaged in the broiler production business and engaged in commercial lines using relatively sub-standard management systems. This activity is being undertaken as a source of income in and around major cities and towns. Their flock sizes usually vary between 2000-5000 broiler chicks. Their production system is characterized by a medium level of feed, water and veterinary service inputs and low biosecurity. Mostly family labor involvement is to the higher side [5].

As it was observed, all farms have some experience how to prevent pathogens from entering into poultry farms with bio-security measures. In almost all broiler poultry houses, there is the practice of periodic disinfection. Equipment used such as feeders and drinkers are appropriate and ensure proper operation (almost the same material used in all farms). Common litter materials used by most farmers are chopped straw, but some are using sawdust as bedding material. Majority of broiler producers sell live chicken and few farms sell stuffed chicken even if they are not legally registered like processors. As indicated in Figure 3, $57 \%$ of the respondents sell their live broilers are farm gates while $23 \%$ to the local market and $19 \%$ at district market. But few processors supply their products to poultry meat collectors, and they sell product for supermarkets and hotels. The selling price of live broilers are determined by the market situation and sometimes the brokers have main a main roll in limiting price. The prices around Debrezeit and Addis Ababa were almost similar. In most cases the price of broilers depends on the season and cost of feed and also their location to the big market. As to the source of feed, more than $50 \%$ of broiler farmers use their feed mills, the rest who have small numbers of broilers they purchase from nearby feed processors.

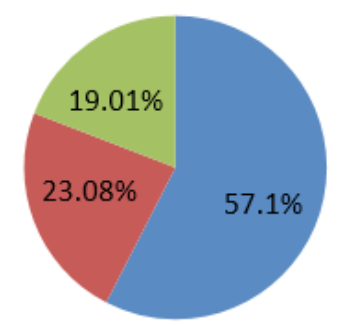

- Farm get

- Local markets

District market

Figure 3: Marketing channel for broilers and broiler meat.

\section{Technical support}

In relation to technical support, from all the support they get, $52 \%$ respondents inform that they get the technical support from MOLF, NGOs and Research Centers. The rest of poultry producers $(48 \%)$ carry out their poultry activities with their own knowledge 
and need technical support (training on broiler production, processing and marketing) from different organizations. Therefore, these small and medium scale broiler farmers are deficient in technical backups of any kind.

\section{Environment control}

All farms tried to prevent odor and pathogens by removing garbage, dead birds, litter materials and other wastes, which is destroyed by burning in pits and/or filling pit by soil. Some are using incinerators for the similar purpose. Small holders which have limited area to destroy dead broilers usually put them in plastic bags and dump them in any open areas which finally causes environmental pollution and potential disease risks. In general, these farmers don't follow the SPS requirements.

\section{Major challenges of broiler production}

Challenges mentioned by broiler producers include limited access to land for poultry production and for the production of maize and soya beans as an input for poultry feed because of inadequate and poor access to quality feed from the local market. Limited access to import parent stock or lack of day old broiler chicks, inefficient animal health service due to lack of drug supplies and quality vaccines, seasonal fluctuation of demand due to fasting seasons and lack of finance, shortage of foreign currency and the absence of protective trade policy to encourage domestic private investors in the poultry business. In addition to these, the poor linkage between the industries and higher learning institutes and the poor inter sectoral relationships also contribute to the poor performance in the sub-sector.

\section{Broiler meat processing features in Ethiopia}

Processed poultry products, including chilled or frozen broiler meat, currently account for a small share of urban household consumption and a negligible share of regional consumption. Chilled whole birds and/or parts can be found in supermarkets and big shops in major cities and are also consumed in institutional settings, including restaurants and hotels. Frozen birds and parts are more difficult to find at the retail level but can be found in shops in major cities and are also marketed by processors directly to hotels and restaurants. Currently there are five licensed poultry product processors with slaughtering and processing facilities EMDIDI [3], Annual Report). Three of them are medium scale and two others are small scale. In another way traditional and backyard poultry slaughtering and processing still accounts for roughly 80 percent of all processed poultry meat supplied in the country. The traditional poultry dressing facility at the small holders or retail level are completely manual, with no apparent sanitary measures with nearly zero cold chain management. Comparatively the modern poultry processing farms, altogether on the average process about 1,386 tons of poultry meat/year EMDIDI [3]. These firms operate under semi-automatic plants or basic processing equipment. Conditions in each of the five plants visited during the study period appeared to be better than the traditional ones and they try to comply with some of the requirements. They are better in using cold stores for the end products, hygiene, machineries, equipment and availability of cold tracks.

\section{Marketing of broilers}

The market structure for poultry products is defined as open (informal) and formal markets (progressive). The informal market is mainly for small scale producers which sell live broilers to the surrounding through a middleman. This type of marketing system becomes dominant mostly during holy days. The market channels for primary and secondary producers are retailers, supermarkets, hotels and diplomatic society. This market system has not yet been well developed logistically and are not well equipped. The average broilers live weight is $2.3 \mathrm{~kg}$ with a dressed weight of $1.4 \mathrm{~kg}$ at a fattening period of around 56 days. There is no current data on the present per capita consumption, but according to the data from Global poultry trend [5], the country's per capita consumption is $0.6 \mathrm{~kg} /$ year. This is lower than the African average which is around $6 \mathrm{~kg}$ and much lower than the world average of $33 \mathrm{~kg}$.

\section{Major Role Players in Poultry Meat Marketing}

\section{International hotels in Addis Ababa and the surrounding}

The result of the current study indicated that $90 \%$ of the interviewed hotels are buying chilled poultry meat from domestic producers and supermarkets except Sheraton Addis and Hilton Hotel, which use chicken meat from both domestic and foreign markets. The main reason given for importing poultry meat from abroad is the deficiency of some value-added to the chicken meat and the quality product in domestic markets. But six international hotels from Addis, two hotels from Adama interviewed mentioned that they didn't import poultry products but still rely on sustainable poultry meat supply with all the required standards. Generally, the major limitations in poultry meat production as per the informants include low quality, packaging problem, limited supply and sustainability, sanitation issue, food safety challenges and the stringent requirements of certification. As observed during our assessment most of the hotels interviewed indicated that they would like to obtain fresh locally produced chicken meat because they have specific requirements in product quality, reliability of delivery, fortified products, diversified products and food safety.

\section{Ethiopian airline}

Ethiopian Airline provides to all its passengers food service consisting of hot meals, hot or cold snacks, or light refreshments, depending on the length of the flight and the time of the day. To satisfy the customers' needs the airline imports different type of food items from abroad. As Ethiopian Airline catering department, on the average they import 2,000 kg chicken cube from Brazil through Dubai and from South Africa. As a main buyer they have specific requirements in product quality, reliability of delivery and product diversification. Like the international hotels, the reason for importing poultry meat from the outside world is limited supply, food safety issues and minimum products type available in the domestic market. According to Ethiopian Revenue and Custom Authority different years' report, the origin and type of poultry meat imported varies. As the ERCA [4] report indicated the type of the poultry products, country of origin and their value is summarized in Table 2. 
Table 2: Age of Respondents (Poultry farm owners).

\begin{tabular}{|c|c|c|}
\hline Age & Number of Respondents & Percentage \\
\hline Below 30 years & 4 & $19 \%$ \\
\hline Above 30 years & 17 & $81 \%$ \\
\hline Total & 21 & $100 \%$ \\
\hline
\end{tabular}

\section{Supermarkets}

Most of the supermarkets in and around Addis Ababa buy packed poultry meat in plastic bags from the middlemen and some producers and resell it to their customers depending upon their customers' preference. They import or buy poultry products from importers to satisfy the local supply gap. Customers from super-

Table 3: Imported Poultry Products type and country of origin. markets are expected to pay on the average 70-80 Birr/kg for fresh locally produced poultry meat but the average price of imported chicken meat costs 110-120 Birr/kg. According to respondents from the supermarkets, the price of poultry meat varies depending on size and the season. On the time of fasting, purchase quantity will decline but the price is the same as with non-fasting time. As it is known, raw foods of animal origin should be stored at the temperature between one and four degrees Celsius. The supermarkets follow this guideline closely. Moreover, they kept their refrigerated poultry meat on an average of seven days. According to those respondents from the supermarket, there is a high consumer demand for chicken meat in the domestic market. In general, the challenges associated to broiler meat supply value chain in Ethiopia are too many, but the major ones are summarized in Table 3.

\begin{tabular}{|c|c|c|c|}
\hline Type of products & Country of origin & Volume in kg. & Worth in USD \\
\hline $\begin{array}{c}\text { Whole frozen chicken, Chicken Breast, Turkey } \\
\text { breast, Poultry sausage, Ham meat Poultry, Canned } \\
\text { chicken, Duck breast and different chicken meat } \\
\text { cuts }\end{array}$ & $\begin{array}{c}\text { Saudi Arabia, Brazil, China, Italy, France, Thailand, } \\
\text { Ukraine, United states, Germany, United Arab Ima- } \\
\text { rets, Turkey, Indonesia, South Africa }\end{array}$ & $244,038.56$ & 378,761 \\
\hline
\end{tabular}

\section{Conclusion}

Poultry production and consumption is a highly growing agribusiness in the world. Moreover, the socioeconomics of poultry production is also acceptable and feasible. This all makes poultry production the preferred production types is supplying the future protein demand of the society. In Ethiopia the poultry sector has a long history, but its growth is very sluggish. There are around 60.04 million chicken in the country of which more than $88 \%$ is local ecotypes with traditional production system. The broiler industry is also at its very infant stage, mostly concentrating in and around Addis Ababa catchments Table 4. There are some broiler farms both small scale and medium types and there are also some broiler meat processing units of different nature. They supply their products to retailers, middlemen, direct to supermarkets and star hotels. But due to the vast demand and supply gap in the poultry meat supply, a huge amount of broiler meat is imported from the outside world. The major reasons why Ethiopia is not self-sufficient in broiler meat production and supply are too many but the major ones include production and processing premises are below set standards the informal marketing channel is dominant, the application of international food safety measures like ISO, HACCP and GMP are literally absent, shortage of skilled manpower in the sector is a very serious problem and the market information system and access to credit and incentive is very minimal. Therefore, because of these interlinked challenges and others, the producers and processors are not competent in the market which resulted in the importation of poultry products to Ethiopia.

Table 4: Summary of Major Challenges Along Broiler Value Chain.

\begin{tabular}{|c|c|c|}
\hline $\begin{array}{c}\text { Challenges Mentioned by Broiler } \\
\text { Producers }\end{array}$ & $\begin{array}{c}\text { Challenges Mentioned by Broiler Meat } \\
\text { Processors }\end{array}$ & $\begin{array}{c}\text { Challenges Mentioned by Hotels Ethiopian Airlines } \\
\text { \& Supermarkets }\end{array}$ \\
\hline 1. Limited access to land & 1. Seasonal fluctuation of demand, & 1. Insufficient and inconsistent supply, \\
\hline 2. High cost of feed \& low quality, & 2. Absence of modern facilities & 2.Absence of modern packaging system, \\
\hline 3. Foreign currency limitations & 3. Limitation of markets access, & 3. Weak business relationship \\
\hline 4. Inefficient animal health service & 4. Inadequate of financial sources & 4. Lack of integration \& linkage \\
\hline 5. Limited attention from the government & 5. Informal and illegal trading, & 5. Limited quality control measures etc \\
\hline & 6. Lack of awareness of the people & \\
\cline { 2 - 3 } & 7.Absence of protective trade policy & \\
\hline
\end{tabular}

\section{Recommendations}

This study has been trying to figure out the major challenges to the poultry industry in Ethiopia and suggest the following recommendations based on the realty on the ground and the existing potentials in the country. a) Support poultry product processors to meet the specific requirements of the costumers through strengthening the broiler production system and establishing standards for specific products.

b) Create awareness among broiler value chain actors on quality and reliability of delivery, encouraging products development and diversifications of poultry meat. 
c) Develop product promotion strategy by creating awareness of the general public and facilitate direct market linkages among value chain actors.

d) Develop and strengthen poultry marketing information system.

e) Strengthening Poultry Producers and Processors Association through government support to reach the major broiler producers and processors.

f) Support and attract investors to invest in poultry industry by using different incentives.

g) Promotion of broiler meat to enhance nutrition and empower women.
The government should develop a policy to regulate the market.

\section{References}

1. CSA (2017/18) Federal Democratic Republic of Ethiopia. Agriculture Sample Survey 2017/18 1:1-53.

2. FAOSTAT (2016) United nation food and agriculture statistics. FAO Rome, Italy.

3. EMDIDI (2017) Ethiopia meat and dairy industry development institute. Annual Report.

4. ERCA (2016) Annual Report of Ethiopia Revenue and Custom Authority, Ethiopia.

5. Jackie Linden (2014) Global poultry trends 2014: Steady rise in chicken meat output for Africa and Oceania. 